\title{
CORRESPONDENCE
}



\section{South African ban}

SIR - I do not wish to enter the debate about British participation in astronomy in South Africa but I must object to some statements in the letter from Dr David Evans (Nature 11 November, p.102).

He states that boycotts of the type proposed are usually ineffective. The only boycott properly applied to South Africa has been in the field of sport, and this has been most effective, leading to integration in most branches. Many of us believe that the same kind of pressure applied to academic circles would achieve a similar result with beneficial consequences for the education of non-whites in that country. An academic boycott might be a blow to some sections of the community (almost all white) but would be welcomed by many others (almost all black) who derive great moral encouragement from manifestations of external sympathy with their cause.

$\mathrm{He}$ is of course right when he says the South African government has a problem of "terrorist activity", although this is a term one prefers not to apply to people who are simply trying to achieve equal rights for themselves. It must of course be evident that South Africa has brought this activity on itself; the problem would not have existed had it not chosen to suppress the majority of its people by refusing to provide ordinary democratic rights. Dr Evans is most certainly a victim of South African propaganda when he refers to the activists as being "inspired by the Soviet Union'. Has he learned nothing at all from events in Zimbabwe? African people want independence and sclf-determination, not replacement of one dominant force by another.

Finally, he may believe that the best hope for a peaceable solution lies in an increase of cultural links from abroad. He must know that South Africa used to enjoy these links fully as part of the British Commonwealth and a respected member of the international community. It chose to isolate itself by inflicting a policy of apartheid on most of its inhabitants. Why should increased contact with the rest of the world achieve more now than it did 35 years ago? R. HOFFENBERG University of Birmingham, Birmingham, UK

\section{Naming enkephalins}

SIR - It is easy, as Morley (Neuropeptides 1, $231-235$; 1981) has pointed out, to be misleading in attempting to specify the structures of enkephalins and their analogues. The commonest confusion may be caused if [Met]enkephalin, for example, is written as Met-enkephalin. This is because IUPAC-IUB recommendations, used throughout peptide chemistry, specify square brackets for substitutions and forms such as "Met-" for $\mathrm{N}$-terminal extensions. Thus the form "Metenkephalin" might well be necessary for extension of the basic sequence Tyr-Gly-GlyPhe-Xaa to Met-Tyr-Gly-Gly-Phe-Xaa. The form [Met] enkephalin seems convenient as a simplification of the strictly systematic [Met ${ }^{5}$ ] enkephalin, which should be used in contexts where ambiguity is conceivable.

The recommendations for C-terminal extension and for partial sequences are illustrated by the identity of

[Leu ${ }^{5}$ ]enkephalinyl-Arg-Arg with dynorphin(1-7) peptide.

References to the many printings of the 1966 IUPAC-IUB recommendations are given by Morley. They are now under revision, but there is no proposal to change appreciably any of the methods of designating $\mathrm{N}$ - and C-terminal extension of peptides, substitutions, deletions and partial sequences. The new recommendations are likely to be published in 1983.

H.B.F. Dixon

Nomenclature Committee of IUB, Cambridge, UK

\section{Chinese seismometry revisited}

SIR - I write with reference to an article on a Chinese seismometer featured in "Nature 100 years ago" (ref.1). You may be interested to learn that the original article carried some errors. According to Joseph Needham ', "Choko" was the Japanese version of the name of Chang Hêng (AD 78-139), a noted astronomer, and his seismometer dates from AD 132 rather than AD 136. Several reconstructive drawings are illustrated in
Needham's book and in 1910 another illustration was presented to this museum by the Japanese Imperial Department of Education.

We currently exhibit a sectioned reconstruction of the seismometer (see below), given by the $\mathrm{BBC}$, which has been demonstrated on television. In 1980 the Chinese Seismological Association presented a small statue of Chang Hêng to the Science
Museum; this too is on exhibition. The seismometer is also figured on one of a set of Chinese postage stamps, on display alongside Chang Hêng and his seismometer in our Geophysics Gallery.

Anita MCConnel.l (Curator)

Science Museum,

South Kensington,

London SW7, UK

1. Nature $299,779(1982)$

2. Needham, J. Science and Civilization in China Vol. 3. 626 (1959).
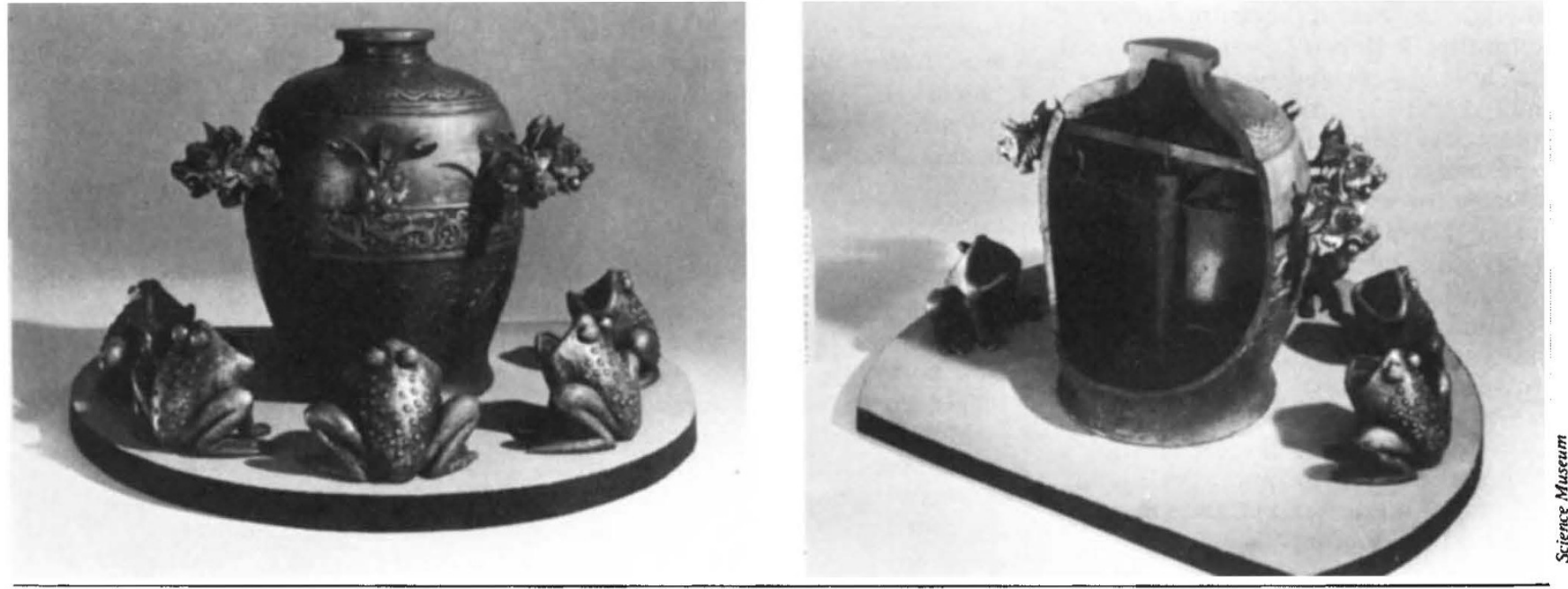